\title{
A UNIQUE MEGALITHIC FIND FROM THE GREAT HUNGARIAN PLAIN Preliminary Report on the Research of a Stone Stele from Kevermes
}

Gergely Bóka $^{1}$ - Attila Gyucha ${ }^{2}$ - István Oláh ${ }^{3}$ - Máté Stibrányi ${ }^{1}$ - Mihály Pethe ${ }^{1}$ - Zsolt Kasztovszky $^{4}$ - Attila KReiter ${ }^{5}$ - Michael L. Galaty ${ }^{6}$ - Timothy J. WARD ${ }^{7}$ - Balázs Szemerey-Kiss ${ }^{8}$ Danielle J. Riebe ${ }^{2}$ - Pál Medgyesi ${ }^{9}$

Hungarian Archaeology Vol. 10 (2021), Issue 4, pp. 9-17. https://doi.org/10.36338/ha.2021.4.4

Large, complex megalithic monuments erected in great numbers on the Atlantic coast and in northern Europe during the 4th-2nd millennia BC have never been found in Hungary, and the architectural forms and decorative arts of passage and chamber tombs, dolmens, stone circles, and menhirs have not been linked to the archaeological heritage of the Carpathian Basin. This is what renders a stone stele, with engravings evoking some megaliths in western Europe, found near Kevermes in the southeastern Great Hungarian Plain so extraordinary. In this article, we report the results of our research related to this unique object to clarify the circumstances of its discovery, to examine the possibility of forgery, to specify the raw material and provenance of the stele, and to explore the original context. In our next paper, we will present detailed descriptions of the analytical results and discuss the interactions and networks that may have led to the appearance of the motifs on the Kevermes stele on the Great Hungarian Plain.

\section{FIND CIRCUMSTANCES}

In February 2008, János Fábián, a retired teacher from Kevermes, visited archaeologist Pál Medgyesi at the Munkácsy Mihály Museum in Békéscsaba. He reported that years earlier a large stone decorated with engravings had been found in the vicinity of Kevermes in Békés County. He hoped Medgyesi might provide more information about its possible origin. Following his visit, we met Mátyás Magyar in Kevermes, who had preserved the object as a decorative ornament in his backyard (Fig. 1).

According to Mátyás Magyar, the artifact was found by the landowner, József Kovács, while plowing a field at the very beginning of the 2000s. We paid a visit to József Kovács, who noted that the plow struck the stone at a depth of about $40 \mathrm{~cm}$ from the surface (this was when deep-plowing was done for the first time in the area). They tried to dig the object free, however, due to its size, eventually they had to use a backhoe to remove it. The discoverer reported that the stone lay at a slight angle in the ground. In order to prevent the object from disturbing future agricultural work, it was placed in a ditch running along the nearby Elek-Lökösháza road. In 2007, during his work, Mátyás Magyar came into contact with József Kovács and, being interested in local history, he inquired about possible antiques. Based on the description provided by József Kovács, Mátyás Magyar found the object that had been in the ditch for years and took it to his home. During our visit to Mátyás Magyar in 2008, we took photos and made drawings of the find.

\footnotetext{
Várkapitányság Zrt. Corresponding author: bokagergely@yahoo.com

2 University of Georgia, Department of Anthropology, USA.

Flame Spray Hungary Ltd.

4 Eötvös Loránd Research Network, Centre for Energy Research, Nuclear Analysis and Radiography Department, Budapest, Hungary.

Hungarian National Museum Laboratory for Conservation and Applied Research, Budapest, Hungary.

6 University of Michigan, Museum of Anthropological Archaeology, USA.

Millsaps College, Keck Center for Instrumental and Biochemical Comparative Archaeology, USA.

The Hungarian University of Fine Arts, Conservation Department, Budapest, Hungary.

9 Munkácsy Mihály Museum, Békéscsaba, Hungary.
} 


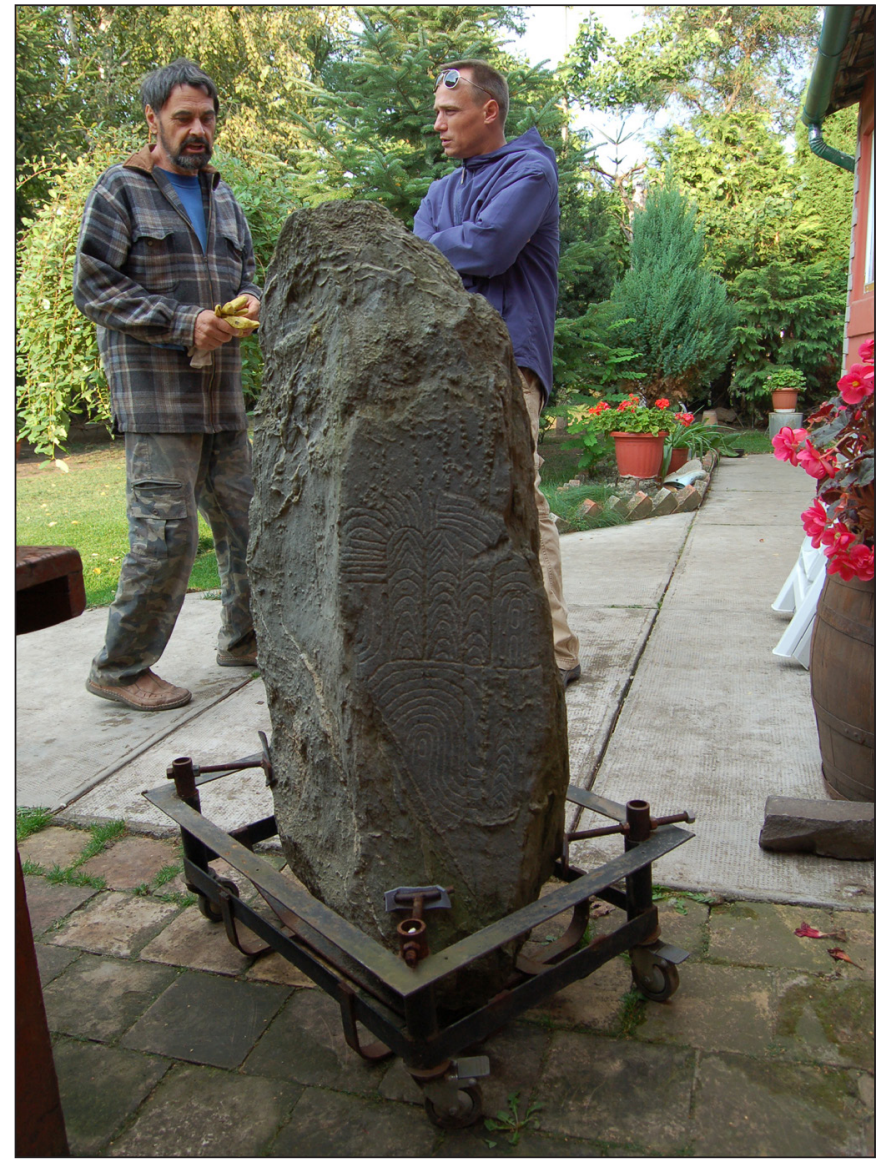

Fig. 1. Mátyás Magyar (left), Attila Gyucha (right), and the stele (front) in the home of Mátyás Magyar in 2008

The green, medium-hard, foliated stone has thin, yellowish layers in its fabric. It is $110-112 \mathrm{~cm}$ high and $48-55 \mathrm{~cm}$ wide. A small, recently damaged section can be observed in the upper right corner of the object, which may have been caused by the plow. The surface of the upwardly tapering body of the object is typically rough and irregular, however, one side has a smooth plane of schistosit. A complex pattern of lines was engraved in a $25 \times 44 \mathrm{~cm}$ area of this surface (Fig. 2).

In 2013, with the assistance of József Kovács, we were able to determine the location of the find within a radius of about 50 meters, on a wider, high bank situated northwest of Kevermes (Fig. 3). During this visit, we found Sarmatian (2nd-4th centuries AD) sherds in the area. The previously unknown site was registered as Kevermes-Kopolya-dülő II. In 2013, with the consent of Mátyás Magyar, the stele was transported to Budapest, to the Center of National Heritage Protection at the Hungarian National Museum. The object was added to the collection of the Munkácsy Mihály Museum in 2020, and is currently on display in the museum's permanent exhibition.

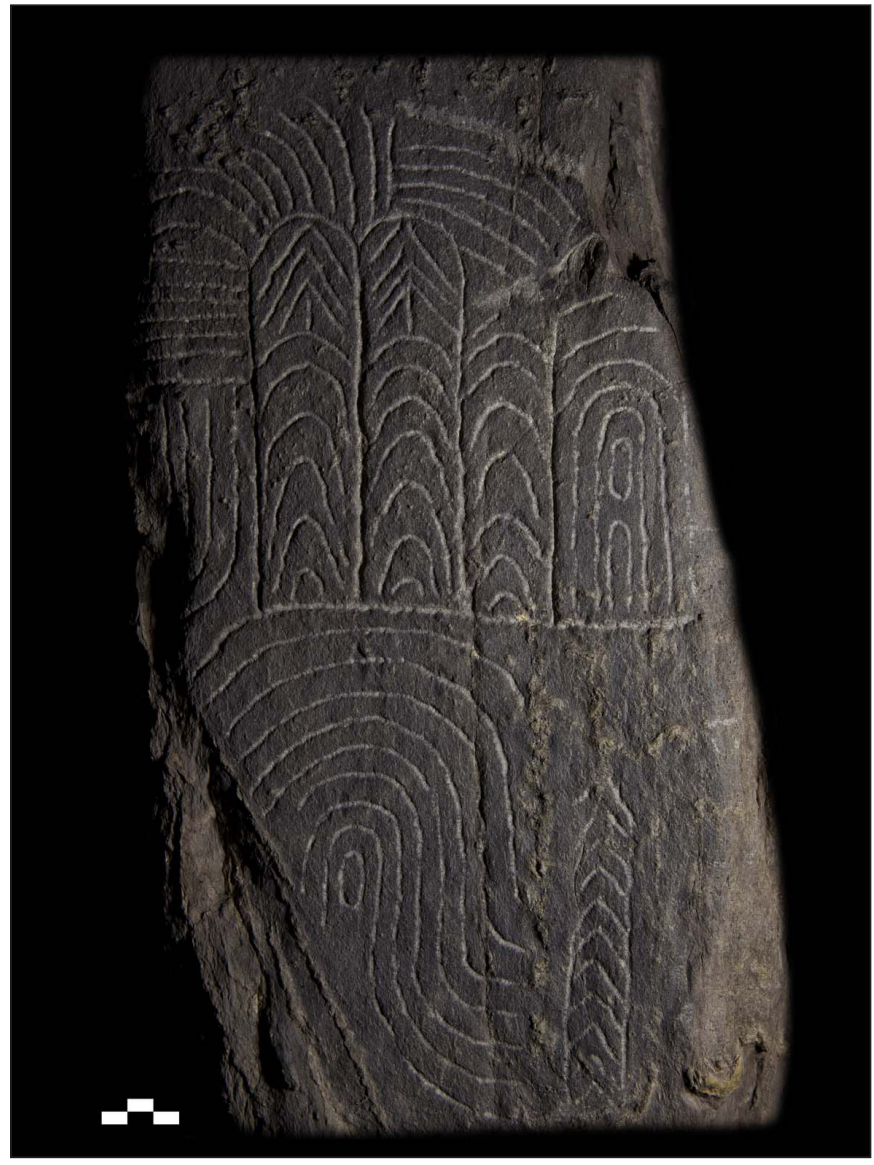

Fig. 2. The engraved side of the stele

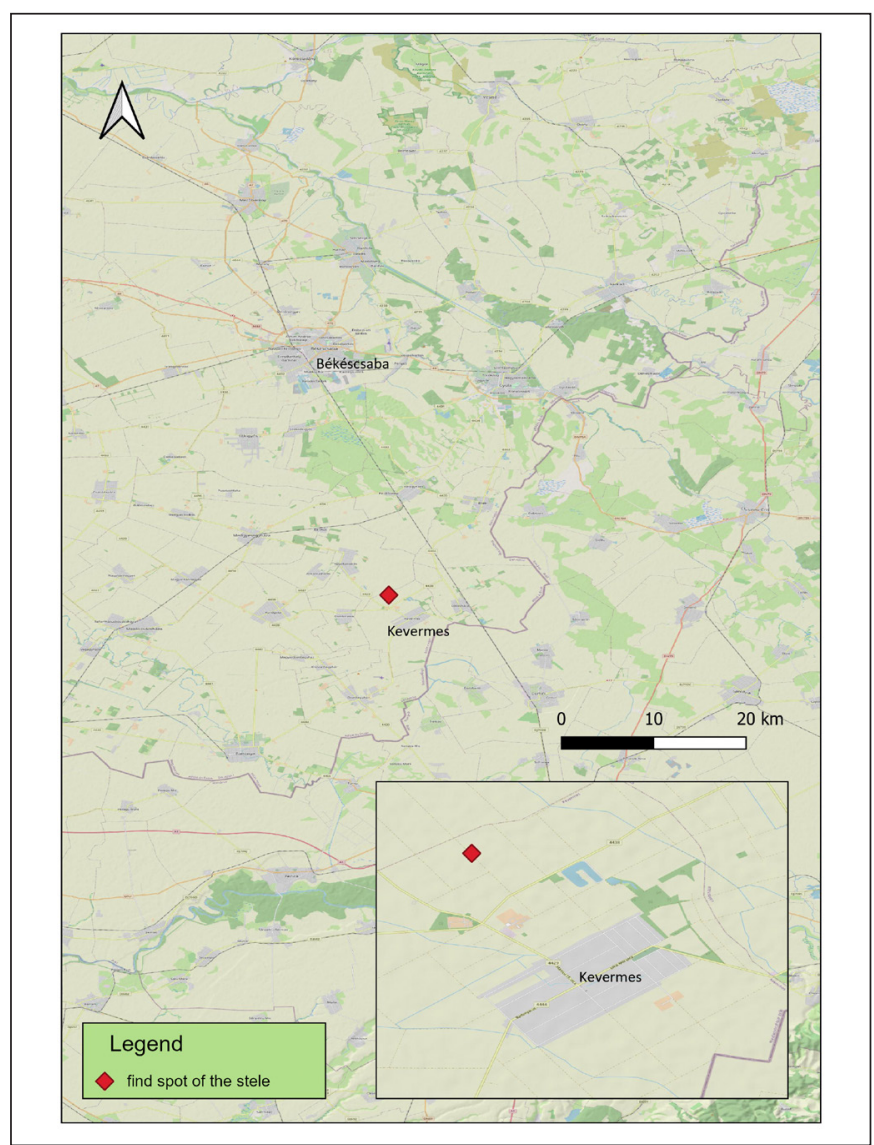

Fig. 3. The find location of the stele 


\section{LABORATORY STUDIES}

In addition to determining the raw material and provenance of the stone, we employed laboratory studies to analyze the production technology of the engravings and to investigate their authenticity. The studies were performed in the Center of National Heritage Protection at the Hungarian National Museum, in the Laboratory of Nuclear Analysis and Radiography of the Energy Research Center of the Eötvös Loránd Research Network, and in the laboratory of the Keck Center for Instrumental and Biochemical Comparative Archaeology, Millsaps College (USA).

\section{Authenticity Investigations}

The motifs on the object are foreign in the archaeological record of the Carpathian Basin, which raised the question of its authenticity. Therefore, one of our most important problems to contend with was to prove the authenticity of the stele's engravings and to rule out possible forgery. To explore this issue, production technological and chemical analyses have been performed.

In preparation for the technological analysis, a three-dimensional image of the object was produced. This high-resolution image is suitable for examining the engravings (Fig. 4). The preliminary results of the technological studies point to the almost flawless execution of the engravings by a careful, experienced hand. Bone, antler, stone, or metal tools may be con-

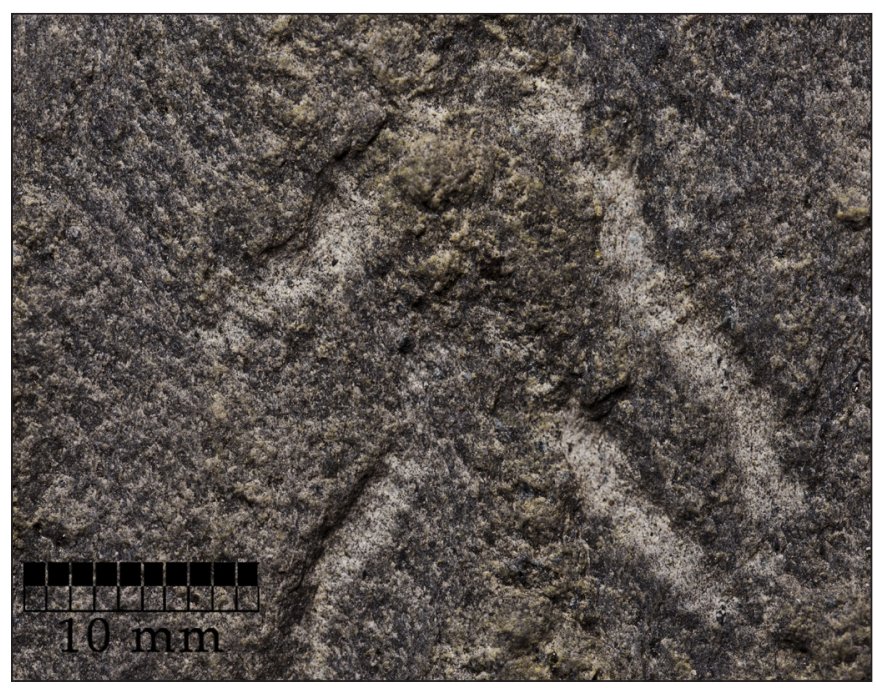

Fig. 4. Detail of the three-dimensional image of the stele sidered as the means by which the motifs were crafted.

Chemical analyses were performed to investigate whether modern metal tools were used to create the engravings. Studies prior to the three-dimensional imaging indicated that the surfaces of the engravings were partially covered with a $\mathrm{CaCO}_{3}$ layer of approximately $0.1-0.05 \mathrm{~cm}$ in thickness. The crust suggests that the object was buried in the upper part of the ground for a relatively long time, where calcite was precipitated in thin layers onto the stone due to fluctuations in local $\mathrm{pH}$ in the groundwater. Chemical traces of manufacturing tools may have been preserved under this calcite layer, therefore, it was removed on the decorated surface as well as on the undecorated back of the stele (blank) with $10 \% \mathrm{HCl}$ solution with the dripping solution collected for analysis. If an alloy (modern) metal tool had been used to create the engravings, the two solutions should have had differences in their chemical compositions. A high-sensitivity method was required for the compositional studies, so ICP-MS (inductively coupled plasma-mass spectrometry) analysis was performed. The measurements of transition metals (chromium, cobalt, vanadium, nickel) and titanium and phosphorus were of particular importance, as, along with iron, these elements occur most frequently in modern alloyed metal tools. The examinations did not reveal any magnitude of difference between the measured elements on the two sides of the stele and no trace of modern metal tool usage was found.

Overall, based on the available information, such as the presence of the calcite layer in the engravings and the results of ICP-MS analysis, there is no evidence to suggest recent manipulation on the object. In addition, during our discussions with those who have had access to the stele over the past 13 years, no such suspicion arose either.

\section{Investigations of Geological Origin}

Macroscopic, petrographic, microprobe, and prompt-gamma activation analyses (PGAA) were conducted to determine the raw material and geological source area of the artifact. According to macroscopic examinations, the most characteristic feature of the rock is heterogeneity, but no specific minerals could be 
identified with the naked eye. Thin-sections from the stone were examined with a polarizing microscope and an electron microprobe (SEM-EDS). The results confirmed the strong heterogeneity of the rock at the microscopic level, showing variation in mineral composition. Subsequently, the chemical composition of the rock-forming minerals was determined using PGAA analysis. As was the case with the petrographic studies, the values measured in the samples corresponded to the chemical composition of greenschist.

The identification of possible source areas for the raw material was based on the chemical compositional values. Many source areas for raw geological materials used for polished stone tools from archaeological sites in Hungary were excluded (e.g., western Hungary, Slovakia, the Czech Republic). Although the Vardar zone in western Serbia was also considered, the Mureş Valley and the Southern Carpathians, which are geographically closest to the site, were identified as the most likely source areas. Due to only a partial geological exploration of these regions and the lack of detailed maps and literature, it was necessary to collect comparative samples.

Therefore, in 2014, we conducted targeted geological sampling in the Mureş Valley and the Southern Carpathians in Romania (Fig. 5). A total of 27 potential sources were visited and sampled. Based on macroscopic, petrographic, and SEM-EDS studies, the greenschist sample collected from the nearest location to Kevermes, about $70 \mathrm{~km}$ away, north of the village of Cladova in the Zaránd Mountains, proved to be identical to the raw material of the stele.

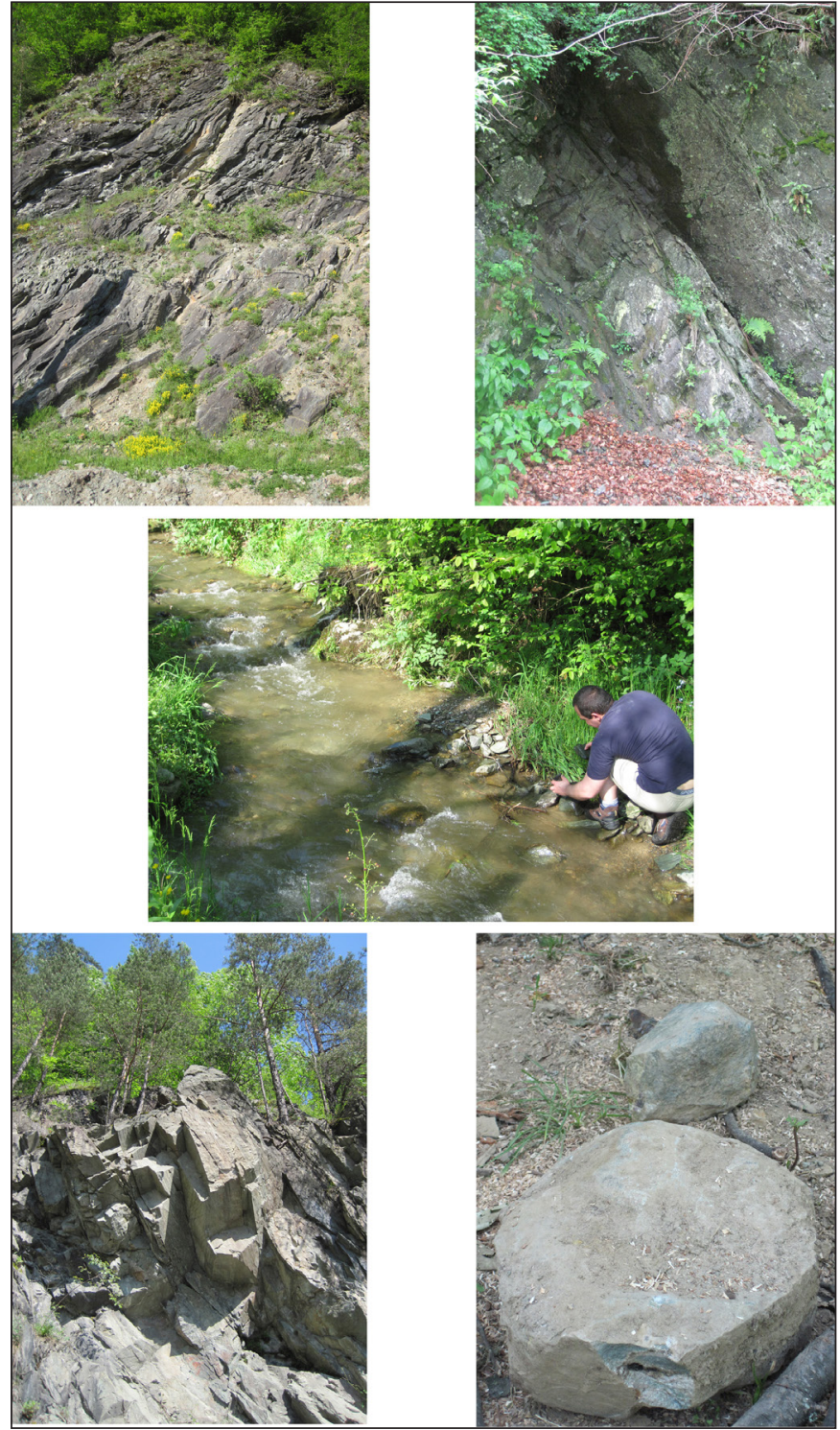

Fig. 5. Photos from our geological sampling in the Mureş Valley and the Southern Carpathians. The middle picture shows István Oláh

\section{FIELD STUDIES}

In addition to laboratory studies, we have conducted surface surveys, geophysical prospection, corings, and excavation in recent years at Kevermes-Kopolya-dülö II to clarify the exact find location and archaeological context of the stele.

\section{Surface Surveys}

During surface surveys in 2013, 2015, and 2020, we found prehistoric and Sarmatian pottery in the broader area of the assumed find spot of the stele. During the collections, fragments of greenschist, the raw material of the stele, were localized across approximately 70 meters in diameter (Fig. 6). Based on the documented spatial pattern, we hypothesized that we had found stone fragments that were broken off the object and scattered as a result of agricultural work within this area, but we also did not exclude the possibility that the surface greenschist fragments might be indicative of a complex megalithic structure extending over a larger area. 


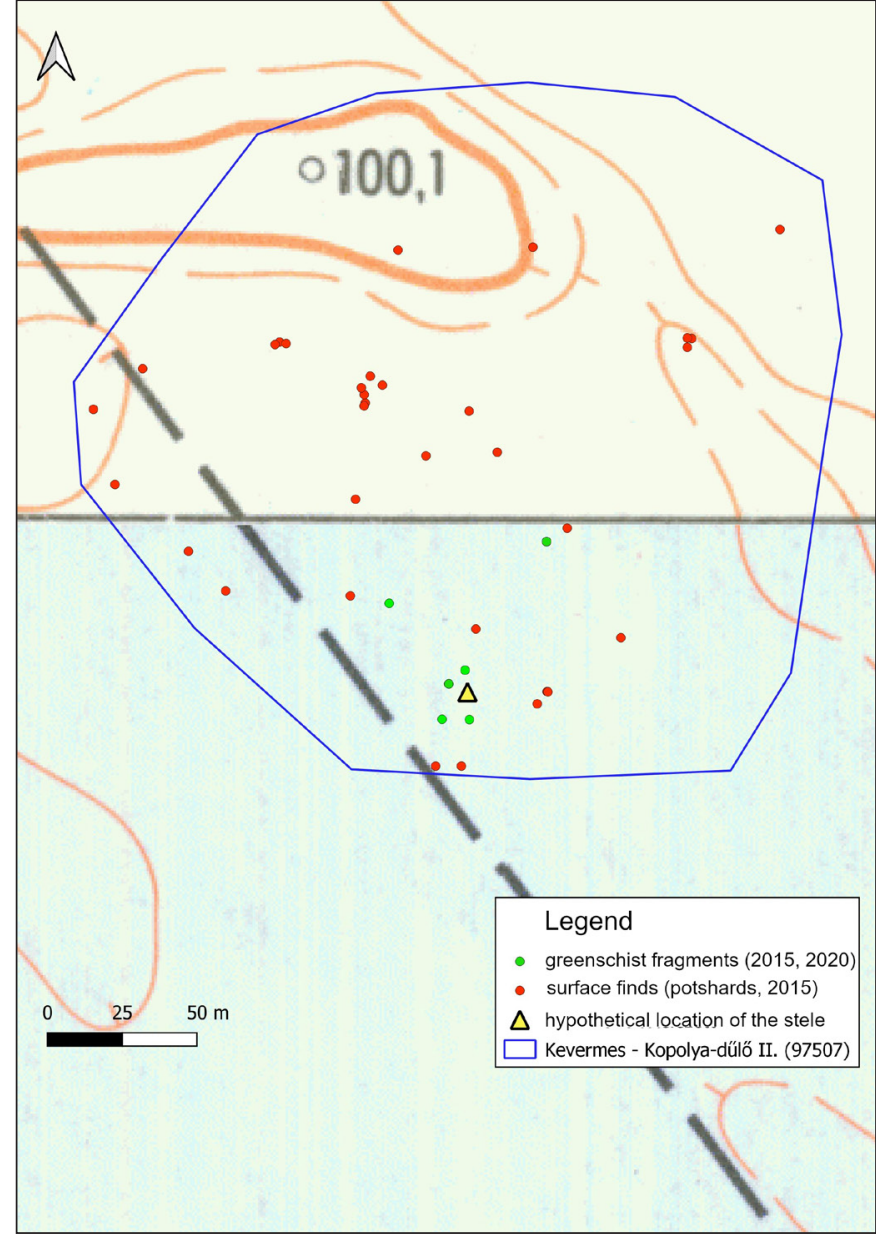

Fig. 6. Distribution of surface finds documented during our surface surveys at the site of Kevermes-Kopolya-dülö II
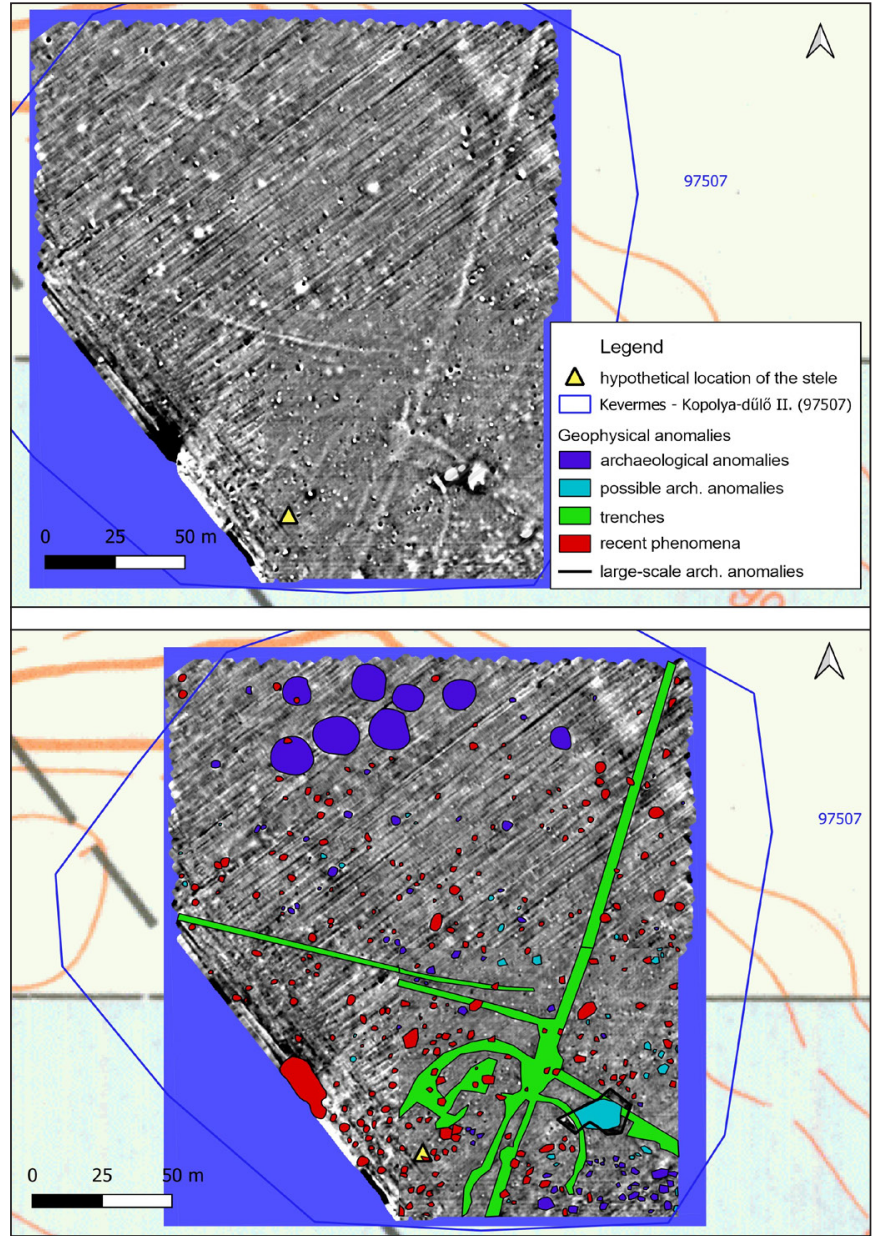

Fig. 7. The result and interpretation of magnetometer prospection at Kevermes-Kopolya-dülö II

\section{Geophysical Prospection}

Based on the surface distribution of greenschist fragments documented in 2013 and 2015, a magnetometer survey was conducted over an area of $100 \times 100$ meters in 2015 . The results suggested scattered settlement features that, judging from the surface finds, likely date to the Sarmatian period. Additionally, the survey detected roads depicted in 18-19th-century military maps, as well as a large, approximately $25 \times 10$ meter, east-west, strong anomaly. In 2019, we continued the magnetometer prospection to the west and north of the area surveyed in 2015, for a total of an additional 2.4 hectares. In addition to the presence of presumably archaeological settlement features, several enclosed burials of a Sarmatian cemetery were recorded in the northwestern part of the surveyed area, concentrated mainly on an east-west ridge (Fig. 7). In order to identify a possible underground structure, and based on the distribution of surface greenschist fragments, we also used ground penetrating radar across an area of $30 \times 30$ meters, but no archaeological features were detected.

\section{Corings}

Based on the magnetometer survey, we considered it conceivable that the above-mentioned strong, about $25 \times 10$-m anomaly could be an underground structure, possibly associated with a burial, where the stele was originally located. To clarify the nature of the anomaly, coring was performed in 2015 at 13 points using an Oakfield hand corer (Fig. 8). A significant amount of iron slag was found in the samples, which precluded the interpretation of the feature, or group of features, as a structure associated with the stele.

In order to study the features detected during the 2015 magnetometer prospection, we continued the coring survey at the site in 2019. Seven geophysical anomalies were examined at a total of 10 points (Fig. 9). 


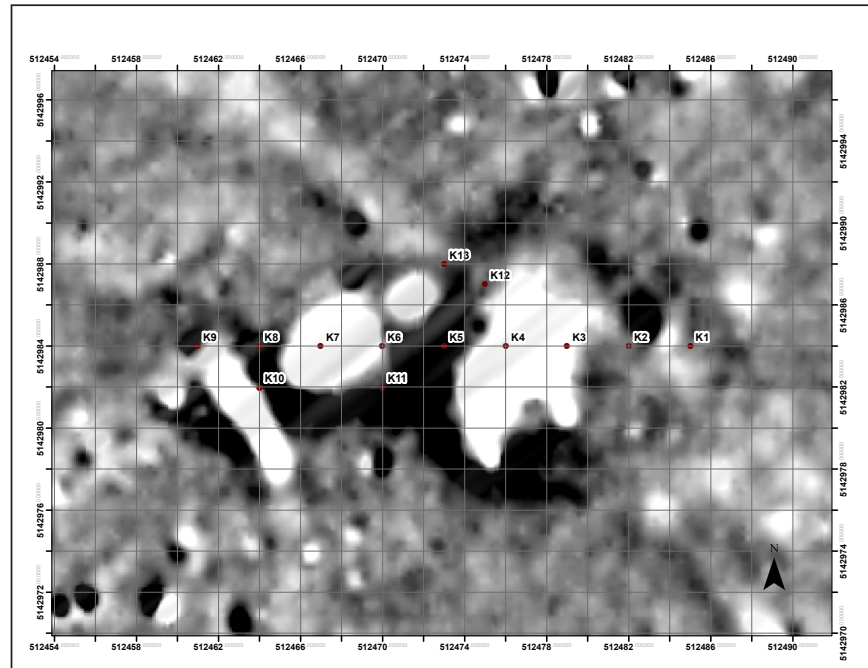

Fig. 8. Coring points in 2015 for the large magnetometer anomaly mentioned in the text

The samples held fill from some settlement features, and additional iron slag pieces were found in four cores placed over the eastern part of the large anomaly examined in 2015. At the westernmost core of this same anomaly, at a depth of $60 \mathrm{~cm}$, we collided with a hard object that was impenetrable with the hand drill. The object was investigated in a $0.5 \times 0.5$ meter test trench, and it proved to be a large piece of iron slag. Our corings and the test trench reaffirmed that the large geophysical anomaly cannot not be associated with the stele.

\section{Excavations}

We had the opportunity to conduct excavations to identify the location and clarify the archaeological context of the stele in 2021 . The $30 \times 30$-meter excavation area was assigned based on the field results in previous years. In the course of our work, we exposed a total of $461.3 \mathrm{~m}^{2}$. We removed the plowzone in two, $2 \times 30$-meter long trenches on both sides of the studied area (Trenches 1-4), while in the center we opened an area of $10 \times 30$ meters (Trench 5) (Fig. 10). In Trench 1, a Sarmatian feature containing ceramics and animal bones was recovered. In the northern half of Trench 2, at the base of the plowzone, some greenschist fragments were found, along with Sarmatian material, but with no associated features (K001). In the southernmost section of the same trench, in clear stratigraphic position, larger, palm-sized greenschist pieces mixed with Sarmatian archaeological materials were uncovered from the fill of a feature dating to the Sarmatian

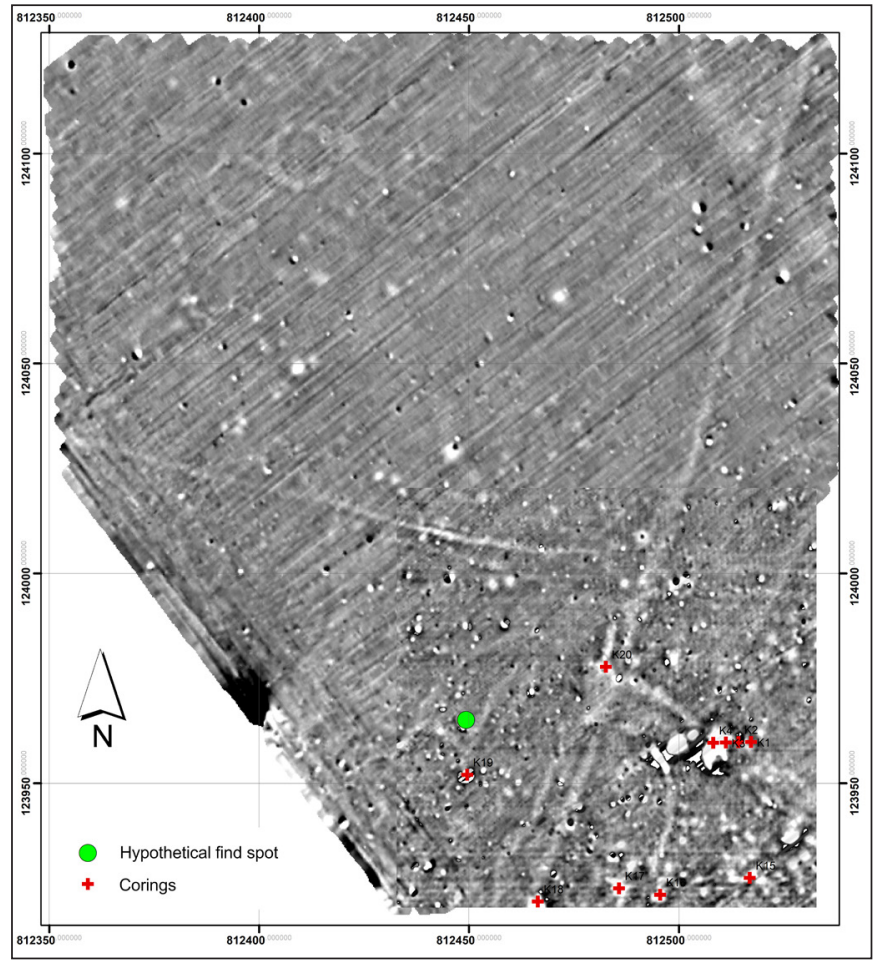

Fig. 9. Coring points in 2019 for various magnetometer anomalies at Kevermes-Kopolya-dülö II

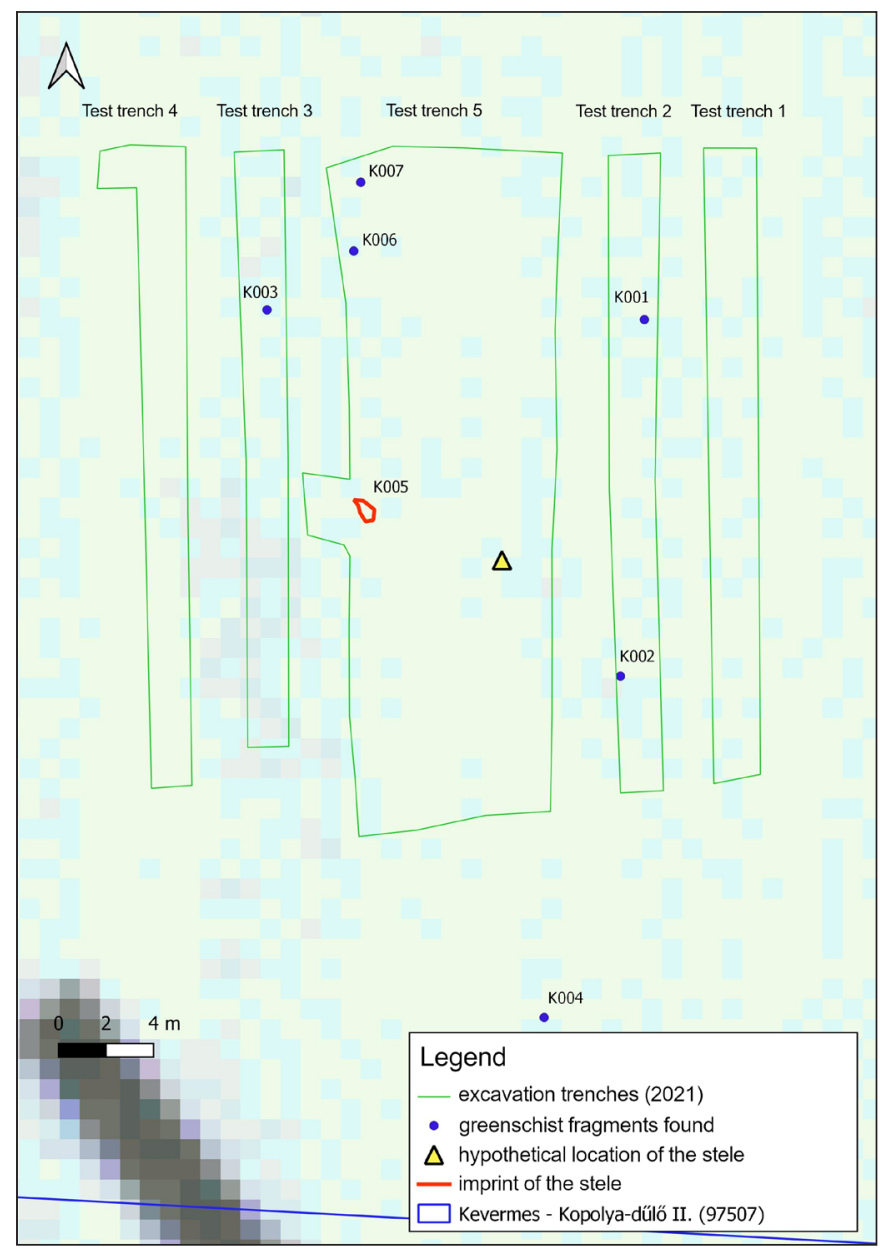

Fig. 10. Excavation trenches and some important observations during the 2021 excavations at Kevermes-Kopolya-dülo" II 
period (K002). Additional greenschist fragments were also excavated in the northern half of Trench 3 , in the fill of a Sarmatian ditch oriented northeastsouthwest (K003). Other than a modern feature, no archaeological features and finds were found in Trench 4. Although a large amount of Sarmatian material was found in the humus layer of the central, 10×30-meter Trench 5, only one archaeological feature was observed at the base of the plowzone (K005). In this shallow, sloping pit, at the depth of $45-50 \mathrm{~cm}$ below the current surface, a weathered greenschist layer of $2-3 \mathrm{~cm}$ in thickness was documented (Fig. 11). The loose, heavily mixed sediment in the feature indicates it was relatively recently backfilled. Some larger pieces of greenschist were also found in the pit fill. Beneath the weathered

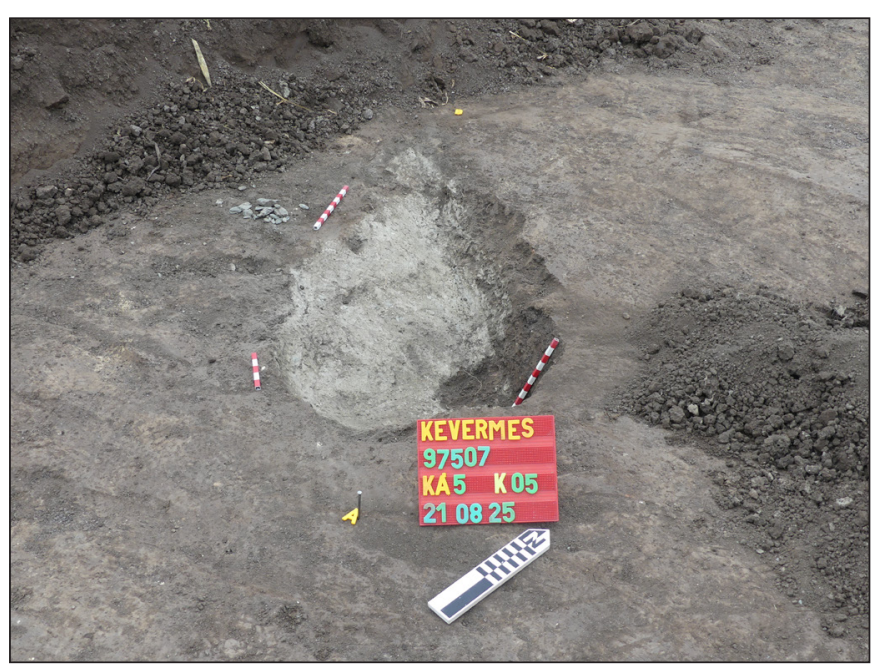

Fig. 11. Feature K005 with the observed greenschist layer and fragments greenschist layer, some small charcoal remains and a small piece of animal bone were recovered and kept as radiocarbon samples. Samples were also collected from the weathered greenschist layer to compare them with the chemical composition of the stele.

The dimensions and shape of the weathered greenschist layer found in the K005 feature make it very likely that we have identified the find location and the imprint of the stele. Our observations suggest that the soil was not disturbed to the base of the stele at the time of its discovery in the early 2000s, only its upper third was dug out, and then the find was pulled diagonally out of the ground with a backhoe. This interpretation is supported by the finder's verbal communication concerning the removal process. No additional archaeological features that could be related to the stele were found in the vicinity of K005.

Based on the available information, the stele might have been transported to its find, presumably secondary, location during the Sarmatian period, between the 2nd and 4th centuries AD. Leaning on its side, it lay in shallow depths and performed an unknown function in the Sarmatian settlement. The additional greenschist fragments found in excavated contexts at the site suggest that in addition to the stele, other greenschist pieces, also presumably larger in size, were collected from the nearby area by the Sarmatians, perhaps from the same context as the stele.

\section{A POSSIBLE INTERPRETIVE FRAMEWORK FOR THE STELE}

PGAA analysis of the greenschist remains found in the K005 feature is currently underway; if the compositional results match those of the stele, the find location of the stele will be identified as the K005 feature. Also, the radiocarbon samples from the K005 feature will be analyzed in the near future, which may confirm our interpretation that the stele was placed in its final, thus find, context during the Sarmatian period. Based on our preliminary results, it can be stated with high probability that the artifact from Kevermes is an authentic archaeological find and not an object recently moved from the Zaránd Mountains to the southern Great Hungarian Plain.

In the archaeological record of the Carpathian Basin, the complex engraved motifs render the stele a unique find. To date, our investigations have not revealed any evidence against the authenticity of the engravings (i.e., modern counterfeiting). The ongoing production technological analyses may provide additional information regarding this as well.

The closest parallels to the engraved motifs of the Kevermes stele occur on the orthostat slabs of the megalithic passage tomb in Gavrinis, Brittany, discovered in the mid-1830s (TwoHIG, 1981, fig. 110-122; Le Roux 1995). The similarity between the motifs on slab No. 24 (L6) from Gavrinis and those of the Kevermes stele is particularly intriguing (Fig. 12). Not only is it striking that all the Kevermes motifs appear in 
the Gavrinis find, but also that the relative position of the individual motifs also shows remarkable similarities. In the megalithic cultures of western Europe, most of the Gavrinis and Kevermes motifs occur individually (TwoHIg, 1981, 55-56, tables 4-5), and they appear very rarely in similar complexity (pl. Newgrange, Ausevik: Burenhult, 2001, 55, fig. 1). A direct connection between the two finds has been refuted by our petrological studies: since the raw materials of the Gavrinis passage tomb are granite, orthrogneiss, migmatite, quartz, and sandstone, our results rule out the possibility - which was unlikely anyway in the first place - that the Kevermes stele was transported to the Great Hungarian Plain from Gavrinis or its vicinity. Given the lack of information concerning its original context, the date of the production for the motifs on the Kevermes stele cannot be determined with absolute certainty. As an approximate analogy, recent studies have placed the use of the Gavrinis passage tomb within a relatively broad time frame, between the first half of the 4th millennium $\mathrm{BC}$ and the transition between the 4th and 3rd millennia BC (Le Roux, 1983; CASSEN et al., 2014; Schulz Paulsson 2017, 65).

Provided this chronological framework is applicable to the stele from Kevermes and, like the finds from Gavrinis and other similar western European sites, our object was utilized in a mortuary context,

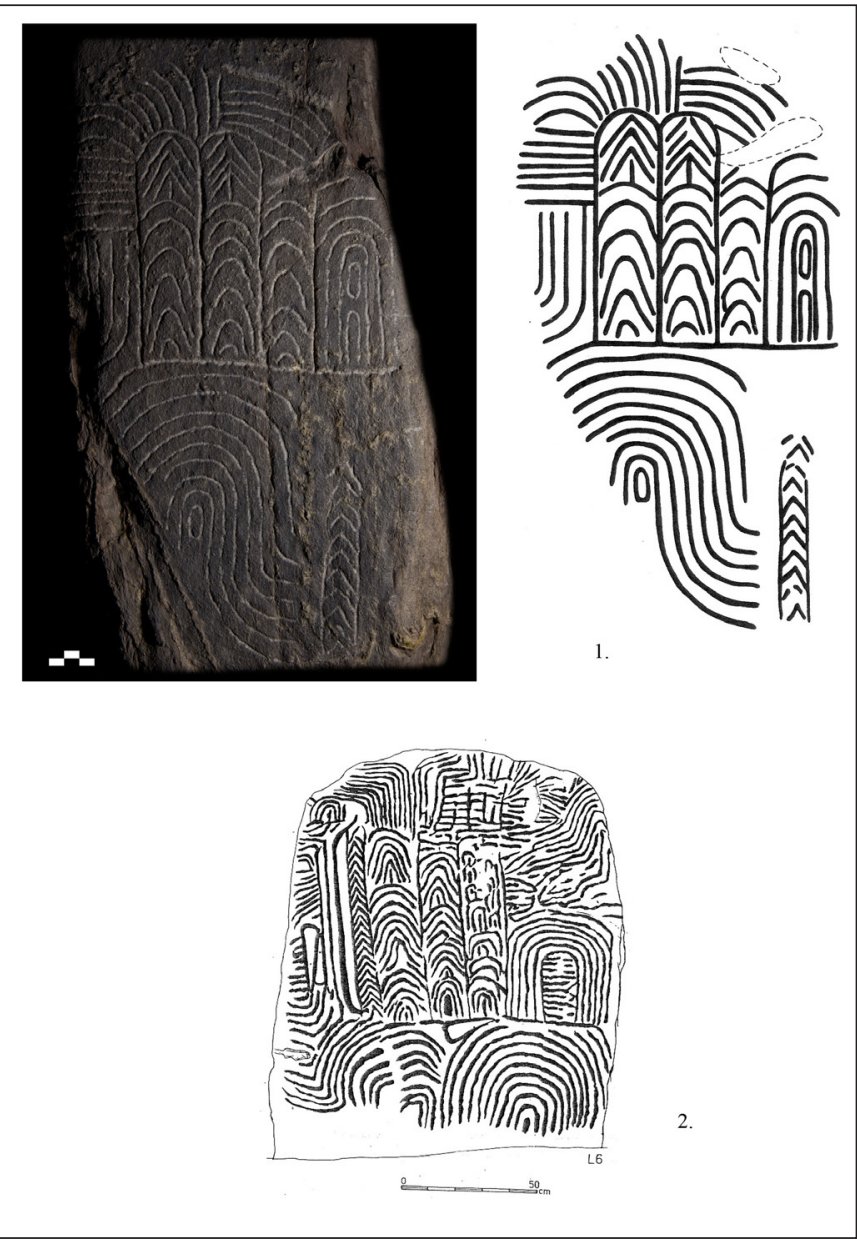

Fig. 12. Motifs from (1) the Kevermes stele and (2) orthostat No. 24 (L6) from Gavrinis. Source for the Gavrinis image: LE ROUX 1995 it is one of the few Late Copper Age stelae known to date from the Carpathian Basin (see Mezőcsát-Hörcsögös: KALICZ, 1999; Budapest-Káposztásmegyer: ENDRŐDI, 1995). The stone, typically anthropomorphic, stelae recovered from the broader region are associated with Yamnaya kurgans that date to the late 4th and early 3rd millennia BC (HEYD, 2012; DiaconesCu, 2020; VIERZIG, 2020). Yamnaya kurgans are known in large numbers across the southeastern Great Hungarian Plain, including the vicinity of Kevermes (ECSEDY, 1979; BEDE, 2014; 2017; DANI et al., 2017). It is conceivable that the Kevermes stele originally belonged to a kurgan, which was disturbed perhaps during construction of the enclosed Sarmatian burials located northwest of the stele's find location, after which the Sarmatians transported the object to their settlement.

Although caution is still warranted with regard to the evaluation of the Kevermes find, our data, collected systematically over the past decade, suggest that the stele is a unique representation of the encounter between the megalithic traditions of western Europe and Yamnaya traditions of the eastern European steppe zone, and may testify to the intensive, diverse, and far-reaching interregional interactions that characterized the continent at the turn of the 4 th and 3rd millennia BC.

\section{REFERENCES}

Bede, Á. (2014). A tiszántúli halmok régészeti geológiai és környezettörténeti szempontú vizsgálati lehetöségei. Doktori értekezés. Szeged: Szegedi Tudományegyetem. 
Gergely Bóka et al. $・$ A Unique Megalithic Find from the Great Hungarian Plain

Bede, Á. (2017). Halomkataszterezési munkálatok a Tiszántúl középső részén. In Benkő E., Bondár M. \& Kolláth Á. (eds), Magyarország régészeti topográfiája: Múlt, jelen, jövő (pp. 45-66). Budapest: MTA BTK Régészeti Intézet.

Burenhult, G. (2001). Long-distance cultural interaction in megalithic Europe: Carrowmore and the Irish megalithic tradition in a western European and Mediterranean context. In B.: Wyszomirska-Werbart (ed.), Cultural Interactions in Europe and the Eastern Mediterranean during the Bronze Age (3000-500 BC), (pp. 47-66). BAR International Series 985. Oxford: Archaeopress.

Cassen, S., Grimaud, V., Lescop, L., Marcoux, N., Oberlin, C. \& Querré, G. (2014). The first radiocarbon dates for the construction and use of the interior of the monument at Gavrinis (Larmor-Baden, France). PAST 77, 1-4.

Diaconescu, D. (2020). Step by Steppe: Yamnaya culture in Transylvania. Praehistorische Zeitschrift 95 (1), 17-47. https://doi.org/10.1515/pz-2020-0010

Ecsedy, I. (1979). The People of the Pit-Grave Kurgans in Eastern Hungary. Budapest: Akadémiai Kiadó.

Endrődi, A. (1995). Erscheinung der Steleerrichtung in Ungarn. Notizia Archaeologiche Bergomensi 3, 305-319.

Dani, J., Márkus, G., Kulcsár, G., Heyd, V., Włodarczak, P., Zitnan, A. \& Peška, J. (2017). A „Yamnaya Impact Project” régészeti topográfiai tanulságai. In Benkő E., Bondár M. \& Kolláth Á. (eds), Magyarország régészeti topográfiája: Múlt, jelen, jövö (pp. 137-150). Budapest: MTA BTK Régészeti Intézet.

Heyd, V. (2012). Yamnaya Groups and Tumuli West of the Black Sea. In E. Borgna \& S. Müller Celka (eds), Ancestral Landscape. Burial Mounds in the Copper and Bronze Ages (pp. 535-555). Lyon: Maison de l'Orient et de la Méditerranée.

Kalicz, N. (1999). A késő rézkori Báden kultúra temetője Mezőcsát-Hörcsögösön és TiszavasváriGyepároson. Herman Ottó Múzeum Évkönyve 37, 57-102.

Le Roux, C.-T. (1983). Bretagne. Gallia Préhistoire 26 (2), 309-333.

Le Roux, C.-T. (1995). Gavrinis. Paris: Editions Jean-Paul Gisserot.

Schulz Paulsson, B. (2017). Time and Stone. The Emergence and Development of Megaliths and Megalithic Societies in Europe. Oxford: Archaeopress.

Twohig, E. S. (1981). The Megalithic Art of Western Europe. Oxford: Clarendon Press.

Vierzig, A. (2020). Anthropomorphic Stelae of the 4th and 3rd Millennia between the Caucasus and the Atlantic Ocean. Proceedings of the Prehistoric Society 86, 111-137. https://doi.org/10.1017/ppr.2020.12 